MÖLLER, Guilherme Christen. A formação do direito processual civil brasileiro contemporâneo. Revista Eletrônica Direito e Política, Programa de Pós-Graduação Stricto Sensu em Ciência Jurídica da UNIVALI, Itajaí, v.13, n.2, $2^{\circ}$ quadrimestre de 2018. Disponível em: www.univali.br/direitoepolitica - ISSN 1980-7791

\title{
A FORMAÇÃO DO DIREITO PROCESSUAL CIVIL BRASILEIRO CONTEMPORÂNEO
}

THE FORMATION OF THE CONTEMPORARY BRAZILIAN CIVIL PROCEDURAL LAW

\section{Guilherme Christen Möller}

SUMÁRIO: Introdução; 2 A construção jurídica do direito processual civil contemporâneo; 2.1 O Regulamento no 737 e os Códigos Processuais Civis Estaduais; 2.2 A unificação dos Códigos Processuais Civis estaduais e o surgimento do Decreto-lei no 1.609/1939; 2.3 O Código de Processo Civil de 1973 (Lei no 5.869/1973) - Código Buzaid; 2.3 O direito processual civil no neoconstitucionalismo: o ínicio quarta fase da ciência processual; 2.4 O Código de Processo Civil de 2015 como ferramenta legislativa potencializadora da nova tendência processual e a constante busca pela efetividade da tutela jurisdicional; Considerações Finais; Referência das fontes citadas.

\section{RESUMO}

Tendo por objetivo a análise da formação da fase contemporânea do Direito Processual Civil brasileiro, este trabalho faz uma abordagem histórica dos principais eventos da ciência processual civil brasileira em sua trajetória, destacando pontos positivos e negativos, iniciando-se com o Regulamento no 737, seguindo para o CPC/39 e o CPC/73, e, ao fim, analisando-se a chave deste estudo, o processo civil no estado neoconstitucionalista brasileiro e o Código de Processo Civil de 2015 como potencializador da nova metodologia processual. Por meio dessa perspectiva, conclui-se que a formação do que temos por processo civil em pleno século XXI deriva de progressos do Direito Processual Civil, em especial dos fenômenos do neoconstitucionalismo e da constitucionalização do processo civil, responsáveis por reformular a visão individualista do processo para socialista e justa, dando ensejo a uma nova fase nessa ciência, necessitando de um Novo Código de Processo Civil para contemplar a nova metodologia jurídica, um Código de Processo Civil cooperativo e justo.

Palavras-chave: Direito Processual Civil; Código de Processo Civil de 2015; Formação contemporânea; Neoconstitucionalismo; Processo cooperativo e justo.

\footnotetext{
1 Mestrando em Direito Público pelo Programa de Pós-Graduação em Direito da Universidade do Vale do Rio dos Sinos (UNISINOS). Bolsista do Programa de Excelência Acadêmica (PROEX) da Coordenação de Aperfeiçoamento de Pessoal de Nível Superior (CAPES). Bacharel em Direito pela Universidade Regional de Blumenau (FURB). Membro do Instituto Brasileiro de Direito Processual (IBDP). Autor de livros e artigos científicos relacionados à Teoria Geral do Processo, Direito Processual Civil e Direito Constitucional. Advogado (OAB/SC n. 51.682) e Consultor Jurídico. E-mail: contato.guilhermecmoller@gmail.com.
} 
MÖLLER, Guilherme Christen. A formação do direito processual civil brasileiro contemporâneo. Revista Eletrônica Direito e Política, Programa de Pós-Graduação Stricto Sensu em Ciência Jurídica da UNIVALI, Itajaí, v.13, n.2, $2^{\circ}$ quadrimestre de 2018. Disponível em: www.univali.br/direitoepolitica - ISSN 1980-7791

\section{ABSTRACT}

With the objective of analyzing the formation of the contemporary phase of Brazilian Civil Procedural Law, this paper addresses the main events of Brazilian civil procedural science in its trajectory, highlighting positive and negative points, beginning with Regulation $n^{\circ} 737$, following the CPC/39 and CPC/73, and, finally, analyzing the key of this study, the civil process in the Brazilian neoconstitutional state and the Code of Civil Procedure of 2015 as lever of the new procedural methodology. Thus, it is concluded that the formation of what we know about civil process in the 21st century derives from progress in Civil Procedural Law, especially the phenomena of neo-constitutionalism and the constitutionalization of civil process, reformulating the individualist view of the process for socialist and just, giving a new phase in this science, requiring a new Code of Civil Procedure to contemplate a new legal methodology, a Code of Civil Procedure cooperative and fair.

Keywords: Procedural Civil Law; Code of Civil Procedure of 2015; Contemporary Formation; Neoconstitutionalism; Cooperative and fair process.

\section{INTRODUÇÃO}

Toda nova codificação, seja processual ou não, depende de prévio debate e discussão, afinal, o objetivo fim de um novo código é aprimorar a própria ciência jurídica e superar "defeitos" que surgiram no decorrer da sua evolução.

Novas codificações são necessárias quando a mera consolidação de questões extravagantes ou de entendimento não forem suficientes para exprimir a nova metodologia de determinado ramo jurídico. Viu-se essa necessidade em 2010 quando da elaboração e apresentação de um Anteprojeto de um novo Código de Processo Civil brasileiro.

A criação do Código de Processo Civil de 2015 não fora ocasional como defendido por parcela da doutrina. Sua elaboração e aprovação foi necessária para que a codificação responsável por ditar os rumos do Direito Processual Civil brasileiro estivesse em conformidade com sua fonte superior, a Constituição Federal.

A diferença entre o Código de Processo Civil de 1973 para o de 2015 não chega a ser tão gritante quando ao do CPC de 1939 para o CPC de 1973, pelo menos não na sua aparência.

A única semelhança entre a codificação processual civil de 1973 e a de 2015 consiste no fato da repetição de determinados dispositivos, ou a ampliação doutros 
MÖLLER, Guilherme Christen. A formação do direito processual civil brasileiro contemporâneo. Revista Eletrônica Direito e Política, Programa de Pós-Graduação Stricto Sensu em Ciência Jurídica da UNIVALI, Itajaí, v.13, n.2, $2^{\circ}$ quadrimestre de 2018. Disponível em: www.univali.br/direitoepolitica - ISSN 1980-7791

apenas para fins de explicar a redação ali contida. Não se tratam de modificações, mas de uma inovação jurídica, afinal o individualismo do CPC de 1973 foi confrontado com ideias socialistas da Constituição Federal de 1988, resultando em uma nova codificação que buscasse um processo cooperativo.

A cooperação não é a única linha metodológica que molda o CPC de 2015. A democracia em que essa codificação foi elaborada e aprovada não pertencia ao momento histórico da elaboração e aprovação dos Códigos de Processo Civil de 1939 e 1973, haja vista que foram elaboradas em regimes de exceção.

Esse ar democrático reformula a visão prolixa e burocrática que se tinha do processo para uma que almejasse um processo justo aos jurisdicionados, com a melhor prestação da tutela jurisdicional e mais fiel à realidade fática do caso, resultando, por conseguinte, numa melhor aplicação do direito material, especialmente versando acerca de garantias fundamentais.

A fase do instrumentalismo processual foi de grande importância para a evolução do que temos por processo civil no Século XXI, entretanto é superada por uma nova fase condizente com as metodologias contemporâneas de processo.

O trunfo do processo civil contemporâneo é justamente essa fase, sendo o Novo Código de Processo Civil o instrumento de efetivação das metodologias por ela incorporadas.

Entretanto, não foi da noite para o dia que a visão contemporânea do processo civil brasileiro foi formada, pelo contrário, longo caminho foi percorrido para que se pudesse chegar a tal momento, inclusive ocorrendo altos e baixos.

Mais do que buscar entender como e por quê o Novo Código de Processo Civil surgiu, é necessário compreender como a fase contemporânea do processo civil foi moldada.

O objetivo deste estudo é analisar os principais pontos da história do Direito Processual Civil que influenciaram para a formação da sua fase contemporânea e no que ela consiste, questionando-se até se o Novo Código de Processo Civil é realmente necessário para a efetividade dessa fase. 
MÖLLER, Guilherme Christen. A formação do direito processual civil brasileiro contemporâneo. Revista Eletrônica Direito e Política, Programa de Pós-Graduação Stricto Sensu em Ciência Jurídica da UNIVALI, Itajaí, v.13, n.2, $2^{\circ}$ quadrimestre de 2018. Disponível em: www.univali.br/direitoepolitica - ISSN 1980-7791

\section{A CONSTRUÇÃo JURÍDICA DO DIREITO PROCESSUAL CIVIL CONTEMPORÂNEO}

\subsection{REgULAMENTO No 737 E OS Códigos PROCESSUAIS CIVIS ESTADUAIS}

Inegável é o fato de que as primeiras marcas do sistema processual civil brasileiro seguem linha similar ao sistema processual civil português, aliás, esse fenômeno de transmigração do Direito é comum em países que foram colonizados, como é o caso do Brasil. ${ }^{2}$

As Ordenação Reais permaneceram em vigência por longo período, até que, dada a progressão na ciência jurídica brasileira e sua independência em relação ao país que foi influente no seu processo transmigração, elaborou-se o Código Comercial, o que resultou, a posteriori, na elaboração do Regulamento no $737^{3}$, caracterizado por ser a primeira fonte positiva ${ }^{4}$ na matéria processual civil brasileira. ${ }^{5}$

Inicialmente, o Regulamento no 737 disciplinava exclusivamente matéria de processo para as causas comerciais, no entanto. essa restrição na matéria abordada pelo referido regulamento resultou na edição do Decreto no 763/1890,

2 ROMANO, Santi. Princípios de Direito constitucional geral. Trad. Maria Helena Diniz. São Paulo: Ed. RT, 1977.

\footnotetext{
${ }^{3}$ O Regulamento no 737 é caracterizado por uma estrutura que se dividia em três partes. A primeira tratava acerca do processo comercial, em caráter geral, abordando questões como juízo e juiz, aplicação da lei comercial, do conflito de leis, competência, conciliação, citação, foro competente, ação ordinária, contestação, reconvenção, provas, ações sumárias, dentre outros assuntos, findandose em sentença. A segunda parte do regulamento é destinada exclusivamente para abordar a execução, e, por fim, a terceira e última parte abordava a matéria de recursos (apelação, embargos, agravos e recurso de revista) e nulidades processuais. BRASIL. Decreto no. 737, de 25 de novembro de $1850 . \quad$ Disponível em: <http://www.planalto.gov.br/ccivil_03/decreto/Historicos/DIM/DIM737.htm>. Acesso em: 6 jul. 2017.

4 O termo "primeira fonte positiva" está atrelado à ideia de primeira codificação realizada sem a influência do Direito português.
}

5 MÖLLER, Guilherme Christen. Anotações sobre a constitucionalização do Direito Processual Civil contemporâneo brasileiro. Curitiba: Prismas, 2017. 
MÖLLER, Guilherme Christen. A formação do direito processual civil brasileiro contemporâneo. Revista Eletrônica Direito e Política, Programa de Pós-Graduação Stricto Sensu em Ciência Jurídica da UNIVALI, Itajaí, v.13, n.2, $2^{\circ}$ quadrimestre de 2018. Disponível em: www.univali.br/direitoepolitica - ISSN 1980-7791

incluindo-se, por força desse decreto e da proclamação da República ${ }^{6}$, além das causas comercias, as causas cíveis. ${ }^{7}$

Marca, esse regulamento, a disputa entre liberais, buscando a ampliação dos poderes locais nos procedimentos e defendendo a descentralização das decisões, e conservadores, almejando essa centralização. ${ }^{8}$

A incorporação, a posteriori, das causas cíveis, resultou em omissões jurídicas para determinadas questões, haja vista o Decreto no 737 ter sido delineado para tratar de questões comerciais, levando a necessidade de aplicar as Ordenações Filipinas ou leis extravagantes nas omissões do decreto ${ }^{9} .10$

O Regulamento no 737 é marco importante para o início da trajetória da ciência processual civil no Brasil, mesmo com peculiar insegurança jurídica, conforme destacado alhures. ${ }^{11}$

Após o advento da Constituição de 1891, no entanto, conferiuse aos Estados a possibilidade de legislar sobre matéria processual, aumentando o espectro de competência antes pertencente somente à União Federal, após o que várias leis

6 PINHO, Humberto Dalla Berdina de. Direito Processual Civil contemporâneo. 5a. ed. São Paulo: Saraiva, 2013, p. 86.

7 MÖLLER, Guilherme Christen. A constitucionalização do direito processual civil contemporâneo brasileiro. 2016. 147 f. Trabalho de Conclusão de Curso (Graduação em Direito) - Centro de Ciências Jurídicas, Universidade Regional de Blumenau, Blumenau, 2016. Disponível em: <http://www.bc.furb.br/docs/MO/2016/362006_1_1.pdf>. Acesso em: 6 jul. 2017.

8 No final das contas, a reforma processual agradou tanto aos liberais, quanto aos conservadores. AGUIAR, Renan; MACIEL, José Fabio Rodrigues. História do Direito. 7. ed. São Paulo: Saraiva, 2016 , p. 267.

9 Um exemplo de omissão jurídica era com relação às ações possessórias, as quais não possuíam qualquer disposição no Regulamento no 737. BRASIL. Decreto n. 737, de 25 de novembro de 1850. Disponível em: <http://www.planalto.gov.br/ccivil_03/decreto/Historicos/DIM/DIM737.htm>. Acesso em: 6 jul. 2017.

${ }^{10}$ AGUIAR, Renan; MACIEL, José Fabio Rodrigues. História do Direito. 7. ed. São Paulo: Saraiva, 2016 , p. 266.

11 THEOdORO JúnIOR, Humberto. Curso de Direito Processual Civil. 57. ed. Rio de Janeiro: Forense, 2016, p. 19. 
MÖLLER, Guilherme Christen. A formação do direito processual civil brasileiro contemporâneo. Revista Eletrônica Direito e Política, Programa de Pós-Graduação Stricto Sensu em Ciência Jurídica da UNIVALI, Itajaí, v.13, n.2, $2^{\circ}$ quadrimestre de 2018. Disponível em: www.univali.br/direitoepolitica - ISSN 1980-7791

foram promulgadas, regulamentando as mais diversas questões processuais. ${ }^{12}$

A Constituição Republicana de 1891, além de estabelecer divisão entre a Justiça Federal e a Justiça Estadual, descentralizou do Estado a competência para legislar sobre matéria processual, o que deu início a uma onda de elaborações de codificações processuais civis estaduais, ficando à União a competência exclusiva para legislar sobre questões processuais civis federais ${ }^{13} \cdot{ }^{14}$

Com ressalvas ao Estado da Bahia e de São Paulo ${ }^{15}$, as disposições acerca do processo em cada Estado não possuíam características singulares, de modo que eram meras adaptações da codificação processual civil federal, Decreto no 3.084/1898, isso em decorrência de um fator fundamental, a ausência de preparo científico dos juristas e legisladores para a atualização e renovação do processo civil em cada Estado. ${ }^{16}$

\subsection{A UNIFICAÇÃO DOS CÓDIGOS PROCESSUAIS CIVIS ESTADUAIS E 0 SURGIMENTO DO DECRETO-LEI No 1.609/1939}

A despreparação científica dos juristas e legisladores estaduais para a elaboração dos Códigos de Processo Civil de cada Estado resultaram em, no termo empregado por THEODORO JÚNIOR, "um tremendo fracasso". Com isso, a Carta constitucional

\footnotetext{
12 PINHO, Humberto Dalla Berdina de. Direito Processual Civil contemporâneo. 5a. ed. São Paulo: Saraiva, 2013, p. 86.

13 Elaborou-se a codificação processual civil da União, aprovada pelo Decreto no 3.084/1898. BERMUDES, Sergio. Comentários ao Código de Processo Civil. São Paulo: RT, 1975, vol. VII, n. 7, p. 35.

${ }^{14}$ BERMUDES, Sergio. Comentários ao Código de Processo Civil. São Paulo: RT, 1975, vol. VII, n. 7 , p. 35.

15 Os Códigos de Processo Civil da Bahia e de São Paulo foram inspiradas no modelo moderno de Direito Processual Civil Europeu, o que ocasionou em quebrar com a mesmice que ocorria noutros Estados. CINTRA, Araújo; DINAMARCO, Cândido Rangel; GRINOVER, Ada Pellegrini. Teoria geral do processo. São Paulo: Malheiros, 2013, p. 74.
}

${ }^{16}$ BERMUDES, Sergio. Comentários ao Código de Processo Civil. São Paulo: RT, 1975, vol. VII, n. 7, p. 35. 
MÖLLER, Guilherme Christen. A formação do direito processual civil brasileiro contemporâneo. Revista Eletrônica Direito e Política, Programa de Pós-Graduação Stricto Sensu em Ciência Jurídica da UNIVALI, Itajaí, v.13, n.2, $2^{\circ}$ quadrimestre de 2018. Disponível em: www.univali.br/direitoepolitica - ISSN 1980-7791

de 1934 buscou centralizar a competência para legislar sobre processo civil unicamente à União (artigo 50, inciso XIX, alínea a, Constituição de 1934) ${ }^{17}{ }^{18}$

Finalmente, a Carta de 1934 consagrou a unificação processual, atribuindo novamente a competência para legislar em matéria processual exclusivamente à União, o que foi mantido pela Constituição de 1937, em seu art. 16, XVI, possibilitando assim a edição do Código Brasileiro de Processo Civil, através do Decreto n. 1.608, de 18 de setembro de 1939. ${ }^{19}$

Diferentemente das codificações estuais, constitui-se uma comissão de experientes cientistas na área processual com a missão de elaborar um Código de Processo Civil brasileiro, todavia, a comissão era dotada por grande divergência acerca das questões processuais entre seus membros. Frente à essa situação, Pedro Batista Martins, membro da comissão originária, elaborou individualmente o projeto da codificação almejada, tendo sido, após quase uma década de estudos e debates, aprovada e transformada no Decreto-Lei no 1.608 , de $1939 .{ }^{20}$

A sua criação foi necessária para a uniformização das normas processuais, "ante o grande número de leis existentes em cada Estado e que, há muito, se faziam obsoletas e incapazes de satisfazer o objetivo primordial do processo civil, qual seja o de tutelar efetivamente os direitos dos particulares"21.

O Código de Processo Civil brasileiro de 1939, assim com o Código de Processo Civil italiano de 1940, nasce numa cultura publicista, "consagrando o processo civil

\footnotetext{
17 Analisando-se a Constituição de 1934, é possível extrair do Art. 50, inciso XIX, alínea "a", a seguinte redação: Art 50 - Compete privativamente à União: XIX - legislar sobre: a) direito penal, comercial, civil, aéreo e processual, registros públicos e juntas comerciais. BRASIL. Constituição da República dos Estados Unidos do Brasil. Disponível em: http://www.planalto.gov.br/ccivil_03/Constituicao/Constituicao34.htm. Acesso em: 6 jul. 2017. Art. 50, inciso XIX, alínea "a".
}

18 THEOdORO JúnIOR, Humberto. Curso de Direito Processual Civil. 57. ed. Rio de Janeiro: Forense, 2016, p. 19.

19 PINHO, Humberto Dalla Berdina de. Direito Processual Civil contemporâneo. 5a. ed. São Paulo: Saraiva, 2013, p. 86.

20 THeOdoro Júnior, Humberto. Curso de Direito Processual Civil. 57. ed. Rio de Janeiro: Forense, 2016, p. 19.

21 PINHO, Humberto Dalla Berdina de. Direito Processual Civil contemporâneo. 5a. ed. São Paulo: Saraiva, 2013, p. 87. 
MÖLLER, Guilherme Christen. A formação do direito processual civil brasileiro contemporâneo. Revista Eletrônica Direito e Política, Programa de Pós-Graduação Stricto Sensu em Ciência Jurídica da UNIVALI, Itajaí, v.13, n.2, $2^{\circ}$ quadrimestre de 2018. Disponível em: www.univali.br/direitoepolitica - ISSN 1980-7791

como o instrumento de realização do bem comum, como todas as outras espécies de atividades do Estado, do qual a autoridade pública se faz porta-voz, dirigido por um juiz que o impulsionava". ${ }^{22}$

Essa característica do CPC de 1939 resulta numa visão "paternalista" do processo, de modo que se busca a verdade e a realização do seu ideal de justiça, com ou sem a colaboração dos jurisdicionados, a iniciativa probatória pelas partes não bastava para a satisfação do processo. O aperfeiçoamento desta ideia resulta no surgimento do processo justo que se tem atualmente. ${ }^{23}$

Forte traço do Código de Processo Civil de 1939 era a sua parte geral inspirada nas legislações alemã, austríaca, portuguesa e nos trabalhos de revisão legislativa italiana, e contando com uma parte especial anacrônica, porquanto da sua fidelidade ao velho processo lusitano caracterizado pela assistemática. ${ }^{24}$

Mesmo sendo um marco demasiadamente relevante para a ciência processual civil no Brasil, o surgimento de uma codificação destinada à regular o processamento das mais variadas questões cíveis, ocorreu uma junção de dois espíritos distintos no Código de Processo Civil de 1939, sendo o primeiro oriundo de ideias inovadoras provenientes do sistema Europeu, refletindo na parte geral, enquanto o segundo possuía um caráter medieval, refletindo na parte especial, responsável por regular questões como procedimentos especiais, os recursos e as execuções. ${ }^{25}$

O Código de 1939 teve o mérito de se inspirar nas mais modernas doutrinas europeias da época, introduzindo importantes inovações em nosso ordenamento processual, como o princípio da oralidade e a combinação do princípio dispositivo e do princípio do juiz ativo, permitindo uma maior agilidade nos procedimentos. O diploma era composto por 1.052 artigos, disposto em dez livros; foi modificado por

22 GRECO, Leonardo. Publicismo e Privatismo no Processo Civil. In: Revista de Processo. vol. 164/2008. Out/2008. p. 29-56.

23 GRECO, Leonardo. Publicismo e Privatismo no Processo Civil. In: Revista de Processo. vol. 164/2008. Out/2008. p. 29-56.

24 BERMUDES, Sergio. Comentários ao Código de Processo Civil. São Paulo: RT, 1975, vol. VII, n. 7, p. 35-36.

25 BERMudes, Sergio. Comentários ao Código de Processo Civil. São Paulo: RT, 1975, vol. VII, n. 7, p. 36. 
MÖLLER, Guilherme Christen. A formação do direito processual civil brasileiro contemporâneo. Revista Eletrônica Direito e Política, Programa de Pós-Graduação Stricto Sensu em Ciência Jurídica da UNIVALI, Itajaí, v.13, n.2, $2^{\circ}$ quadrimestre de 2018. Disponível em: www.univali.br/direitoepolitica - ISSN 1980-7791

diversas leis extravagantes e se manteve em vigor até o último dia do ano de $1973 .{ }^{26}$

Não é possível dizer que o CPC de 39 possuía poucas virtudes. Essa legislação consistia na adoção de doutrinas modernas (para àquela época) e transformou o processo num instrumento de desempenho da função jurisdicional, o norteando por bases principiológicas como oralidade e publicidade, e do juiz ativo. Todavia, por conta da junção de espíritos alhures destacada, o Código de 1939 apresentava inúmeros defeitos, especialmente quanto aos procedimentos especiais, recursos e à execução. ${ }^{27}$

Pode-se dizer que o país atravessou uma grande crise, de processo e de justiça. Os processos se tardavam cada vez mais e se iam amontoando, sem solução, tanto no juízo de primeiro grau como nos tribunais, mui particularmente no Supremo Tribunal Federal. ${ }^{28}$

\subsection{O CÓdIgO DE PROCESSO CIVIL DE 1973 (LEI No 5.869/1973) - CÓDIGO BUZAID}

O surgimento do Código de Processo Civil de $1973^{29}$ não foi uma simples reforma da legislação processual brasileira, pelo contrário, representa uma grande

\footnotetext{
26 PINHO, Humberto Dalla Berdina de. Direito Processual Civil contemporâneo. 5a. ed. São Paulo: Saraiva, 2013, p. 86.
}

27 SANTOS, Moacyr Amaral. Primeiras linhas de Direito Processual Civil. 28a. ed. São Paulo: Saraiva, 2011, p. 78.

28 SANTOS, Moacyr Amaral. Primeiras linhas de Direito Processual Civil. 28a. ed. São Paulo: Saraiva, 2011, p. 78.

${ }^{29}$ O primeiro livro dessa codificação, processo de conhecimento, incorporou a parte geral e serviu de parâmetro para omissões dos demais livros e, além disso, disciplinava matérias relacionadas ao Órgão Judicial, às partes e procuradores, a competência, os atos processuais, os procedimentos comuns, ordinário e sumário, os meios de prova, a sentença, a coisa julgada, os recursos e a tramitação dos processos nos tribunais superiores. O livro dois, por sua vez, apresentou sistematização à execução, eliminando a divergência entre ação executiva e ação executória, impondo apenas, a partir da vigência do novo código, a execução forçada, seja por título judicial, quanto por título extrajudicial. Extinguiu-se o concurso de credores, o que nada mais era do que um simples incidente da execução singular, tendo sido substituído pela insolvência civil, ou seja, a falência de um devedor civil, eliminando-se assim, também, a discriminação que era feita entre comerciante e o devedor civil quando da matéria de insolvência. O livro que disciplinava as cautelares era o de número três, livro que demonstrou um grande avanço para o Direito brasileiro, mesmo que, ainda, muito distante do processo Europeu. Esse livro regulamentou de forma autônoma e completa o processo cautelar, inclusive, em bases sólidas. No tocante aos procedimentos especiais, o livro quatro, além de reduzir muitos outros procedimentos especiais existentes nas legislações passadas, separou os procedimentos de jurisdição voluntária e de jurisdição contenciosa, adotando, para os procedimentos de jurisdição voluntária, um procedimento geral ou comum, dependendo do caso, o 
MÖLLER, Guilherme Christen. A formação do direito processual civil brasileiro contemporâneo. Revista Eletrônica Direito e Política, Programa de Pós-Graduação Stricto Sensu em Ciência Jurídica da UNIVALI, Itajaí, v.13, n.2, $2^{\circ}$ quadrimestre de 2018. Disponível em: www.univali.br/direitoepolitica - ISSN 1980-7791

atualização, assinalando uma nova etapa na evolução do Direito Processual Civil no Brasil e dando início a fase instrumental do processo no Brasil. ${ }^{30}$

Inaugurou-se a Fase instrumental, pela qual o processo não seria um fim em si mesmo, mas um instrumento para assegurar direitos. Com isso, surgiu a relativização das nulidades e a liberdade das formas para maior efetivação da decisão judicial. ${ }^{31}$

O Ministro BUZAID, responsável por elaborar o projeto do Código de Processo Civil de 1973 (surgindo daí a referência ao CPC/73 como Código Buzaid), entendia que, considerando a quantidade de leis extravagantes que tratavam acerca do processo, representando espécies de "cirurgias" ao Código de Processo Civil de 1939, considerando, ainda, as diversas lacunas e falhas existentes na codificação de 1939, seria mais fácil a criação de um novo diploma do que apenas a correção do existente à época. ${ }^{32}$

A grande característica dessa codificação está na tríplice divisão do processo civil em processo de conhecimento, processo de execução e processo cautelar, divisão inspirada em linhas modernas do Direito Europeu. ${ }^{33}$

A superioridade técnica do novo diploma marcou um grande avanço no campo processual civil, muito embora o modelo

que foi uma reforma de grande utilidade processual. Além disso, o livro quatro, conferiu, ao juiz, poderes de apreciação e decisórios para os pleitos não contenciosos, inobstante à critérios de legalidade escrita, nos termos do artigo 1.109 da Lei no 5.869, de 1973, "podendo adotar em cada caso a solução que reputar mais conveniente ou oportuna". A problemática existente nessa legislação foi justamente o quinto livro, as disposições finais e transitórias, livro que continha apenas dez artigos. Essa sumarização dos dispositivos do livro quinto demonstrou certo menosprezo por parte dos legisladores quanto às questões transcendentais, a exemplo, o Direito intertemporal, de modo que tiveram que ser resolvidas pela doutrina e pela jurisprudência. THEODORO JÚNIOR, Humberto. Curso de Direito Processual Civil. 57. ed. Rio de Janeiro: Forense, 2016, p. 21. BRASIL. Lei no 5.869, de 11 de janeiro de 1973. Código de Processo Civil. Disponível em: http://www.planalto.gov.br/ccivil_03/leis/L5869.htm. Acesso em: 6 jul. 2017.

30 THEODORO JÚNIOR, Humberto. Curso de Direito Processual Civil. 57. ed. Rio de Janeiro: Forense, 2016, p. 20.

31 PINHO, Humberto Dalla Berdina de. Direito Processual Civil contemporâneo. 5a. ed. São Paulo: Saraiva, 2013, p. 86.

32 PINHO, Humberto Dalla Berdina de. Direito Processual Civil contemporâneo. 5a. ed. São Paulo: Saraiva, 2013, p. 87.

33 TheOdORO JÚnIOR, Humberto. Curso de Direito Processual Civil. 57. ed. Rio de Janeiro: Forense, 2016, p. 20-21. 
MÖLLER, Guilherme Christen. A formação do direito processual civil brasileiro contemporâneo. Revista Eletrônica Direito e Política, Programa de Pós-Graduação Stricto Sensu em Ciência Jurídica da UNIVALI, Itajaí, v.13, n.2, $2^{\circ}$ quadrimestre de 2018. Disponível em: www.univali.br/direitoepolitica - ISSN 1980-7791

processual ainda repousasse suas bases em institutos individualistas de tutela jurisdicional. ${ }^{34}$

Essa característica marcante do Código de Processo Civil de 1973, o individualismo, resultou, a posteriori, na necessidade de modificações constantes no seu texto por meio de edições de leis extravagantes.

Frente a forte tendência democrática e de movimentos sociais na seara do Direito Constitucional, oriundas da Europa continental pós-guerra e ganhado força no Brasil após a Ditadura Militar e promulgação da Constituição Federal de $1988^{35}$, viu-se a necessidade de adaptar o Direito Processual Civil às novas concepções, buscando a valorização do social, afinal, o direito de ação, as condições da ação, pressupostos processuais e toda a desenvoltura do processo foram planejadas e desenvolvidas na ideia individualista do Código de Processo Civil de $1973 .{ }^{36}$

Nos últimos anos da vigência do CPC/73, o legislador brasileiro, buscou renovar o ordenamento jurídico formal, sob forte crítica e orientação de CAPPELLETTI, o qual reclamava por uma revisão dos rumos em que o Direito Processual Civil estava caminhando 3738 .

Além da preocupação com o caráter coletivo do Direito Processual Civil, o Código de Processo Civil de 1973 sofreu alterações com o objetivo de acelerar a prestação

34 PINHO, Humberto Dalla Berdina de. Direito Processual Civil contemporâneo. 5a. ed. São Paulo: Saraiva, 2013, p. 88.

35 Como a II Guerra Mundial foi responsável por trazer o "caos" a Europa de forma geral, iniciouse um forte movimento de busca pela preocupação coletiva sobre a do individual, refletindo essa ideia nas correntes do pós-positivismo. Similar à Europa ocorreu no Brasil com o movimento da Ditadura Militar, ocasionando na adesão das visões socialistas oriundas da Europa Continental. BARROSO. Neoconstitucionalismo e Constitucionalização do Direito (O Triunfo Tardio do Direito Constitucional no Brasil). Revista da EMERJ. 2006, p. 5.

36 THEODORO JÚNIOR, Humberto. Curso de Direito Processual Civil. 57. ed. Rio de Janeiro: Forense, 2016, p. 21.

37 Buscou-se, com isso, a criação de novos remédios de caráter social e coletivo, a exemplo, a ação civil pública, o mandado de segurança coletivo e o juizado especial civil, destinado às pequenas causas.

38 THEODORO JÚNIOR, Humberto. Curso de Direito Processual Civil. 57. ed. Rio de Janeiro: Forense, 2016, p. 22. 
MÖLLER, Guilherme Christen. A formação do direito processual civil brasileiro contemporâneo. Revista Eletrônica Direito e Política, Programa de Pós-Graduação Stricto Sensu em Ciência Jurídica da UNIVALI, Itajaí, v.13, n.2, $2^{\circ}$ quadrimestre de 2018. Disponível em: www.univali.br/direitoepolitica - ISSN 1980-7791

da tutela jurisdicional ${ }^{39}$, tornando-a mais econômica e mais informal/flexível, especialmente para alcançar melhores resultados práticos aos jurisdicionados. ${ }^{40}$

A própria figura do Juiz sofreu considerável modificação por conta da Lei no 8.952/9441, rompendo-se com a actio iudicati e o autorizado a tomar medidas satisfativas do direito subjetivo material do litigante em casos de urgência, mesmo que no curso do processo de conhecimento. A figura do Juiz contemporâneo passou a ser assimilada com a do pretor romano, de modo que decretava os interditos antes do julgamento definitivo da causa, isso em nome de uma efetividade da relação processual. ${ }^{42}$

Para THEODORO JÚNIOR, o "nosso processo civil, assim, assumiu, em caráter geral, o feitio interdital, reclamando de seus operadores uma profunda revisão e readequação das posturas interpretativas clássicas". ${ }^{43}$

Contudo, as alterações que vêm sendo feitas no atual CPC caminham, desde 2010, em paralelo com a tramitação do projeto para um novo Código de Processo Civil. Considerado o bom material da atual legislação, mas buscando também dispositivos inovadores e modernizantes, não se trata de uma grande reforma, mas, sim, de um novo Código. ${ }^{44}$

39 São exemplos dessas reformas: a tutela antecipatória, o novo perfil para o agravo de instrumento, o reforço da executividade das obrigações de fazer e não fazer, a outorga de autoexequibilidade a todas as sentenças condenatórias, a ampliação dos títulos passíveis de execução, a racionalização do procedimento sumário, a elaboração da ação monitória, dentre outros pontos. Todas essas reformas trouxeram uma nova aparência para o Código de Processo Civil de 1973, surgindo-se uma nova estrutura para essa codificação, a qual foi responsável por além de anular grande parte das disposições antigas, zelar pela efetiva prestação da tutela jurisdicional do processo de conhecimento e do processo de execução. THEODORO JÚNIOR, Humberto. Curso de Direito Processual Civil. 57. ed. Rio de Janeiro: Forense, 2016, p. 22.

40 THEOdORO JÚNIOR, Humberto. Curso de Direito Processual Civil. 57. ed. Rio de Janeiro: Forense, 2016, p. 22.

41 BRASIL. Lei no 8.952, de 13 de dezembro de 1994. Disponível em: <http://www.planalto.gov.br/ccivil_03/leis/L8952.htm>. Acesso em: 6 jul. 2017.

42 THEODORO JÚNIOR, Humberto. Curso de Direito Processual Civil. 57. ed. Rio de Janeiro: Forense, 2016, p. 22.

43 THEODORO JÚNIOR, Humberto. Curso de Direito Processual Civil. 57. ed. Rio de Janeiro: Forense, 2016, p. 22.

44 PINHO, Humberto Dalla Berdina de. Direito Processual Civil contemporâneo. 5a. ed. São Paulo: Saraiva, 2013, p. 88. 
MÖLLER, Guilherme Christen. A formação do direito processual civil brasileiro contemporâneo. Revista Eletrônica Direito e Política, Programa de Pós-Graduação Stricto Sensu em Ciência Jurídica da UNIVALI, Itajaí, v.13, n.2, $2^{\circ}$ quadrimestre de 2018. Disponível em: www.univali.br/direitoepolitica - ISSN 1980-7791

Similar à dúvida de BUZAID, essa onda de modificações no Código de Processo Civil de 1973 levou a pensar se seria necessário a elaboração de um novo Código de Processo Civil, ou se a mera consolidação das disposições extravagantes bastava para suprir essa reformulação de preceitos processuais, ainda mais com a crescente socialização do Direito em decorrência do início de um novo direito constitucional no Brasil.

A história mostra - para quem tem nela interesse - os contextos culturais em que se fazem oportunas as codificações. Pense-se, por exemplo, na passagem do Código de 1939 ao Código Buzaid. Quando Alfredo Buzaid apresentou seu Anteprojeto de Código de Processo Civil, seu objetivo estava em revolucionar metodologicamente 0 direito processual civil brasileiro. Não é preciso muito esforço argumentativo sobre o ponto. É de domínio comum o fato de Alfredo Buzaid ter colocado o processo civil brasileiro, no plano normativo, em fina sintonia com o que de melhor havia se produzido em termos de dogmática processual civil na primeira metade do século XX no Velho Continente e, muito especialmente, na Itália. Com o Código Buzaid, houve em grande parte ruptura com a tradição do direito luso-brasileiro ainda presente no Código de 1939. A diferença entre o Código Buzaid e o Código de 1939, como todos sabem, é abissal É evidente aí a preponderância do intento de ruptura. ${ }^{45}$

\subsection{O DIREITO PROCESSUAL CIVIL NO NEOCONSTITUCIONALISMO: O ÍNICIO QUARTA FASE DA CIÊNCIA PROCESSUAL}

Definir o que viria a ser neoconstitucionalismo ou "novo direito constitucional" é uma tarefa árdua, isso por um simples fator, as incontáveis divergências sobre a questão.

Em linhas gerais, esse "novo direito constitucional" é originário a partir do século $\mathrm{XX}$, sendo fruto de mudanças de paradigmas de estudos doutrinários e

\footnotetext{
45 MARINONI, Luiz Guilherme. MITIDIERO, Daniel. O projeto do CPC - Críticas e propostas. São Paulo: Editora Revista dos Tribunais, 2010, p. 56.
} 
MÖLLER, Guilherme Christen. A formação do direito processual civil brasileiro contemporâneo. Revista Eletrônica Direito e Política, Programa de Pós-Graduação Stricto Sensu em Ciência Jurídica da UNIVALI, Itajaí, v.13, n.2, $2^{\circ}$ quadrimestre de 2018. Disponível em: www.univali.br/direitoepolitica - ISSN 1980-7791

jurisprudenciais, enxergando a Constituição como centro da hermenêutica jurídica, a qual passa a exercer supremacia forma e material. ${ }^{46}$

Originária da Europa Continental pós-guerra, sua ideia é acolhida no Brasil e da ensejo ao início de uma nova fase para o Direito Constitucional brasileiro, isso a partir de 1985 após a Ditadura Militar, ganhando força com a promulgação da Constituição Federal de $1988^{47} .48$

A mudança do centro da hermenêutica jurídica brasileira, ou seja, a Constituição Federal, acaba por afetar os extremos dessa hermenêutica, no caso as legislações infraconstitucionais ${ }^{49}$.

A cultura individualista que se tinha na ciência processual representou um embargo para a adequação do Direito Processual Civil a essa nova visão. Os Códigos de Processo Civil de 1939 e 1973 foram elaborados em regimes de exceção, fator que faz "com que a busca da socialização padeça de dificuldades mais complexas". 50

No cenário do final do século passado, o sistema hermenêutico brasileiro contava com um Código de Processo Civil (CPC/73) baseado em ideias individualistas e com forte cultura à instrumentalização do processo, e, ao mesmo tempo, uma

\footnotetext{
46 BARROSO. Neoconstitucionalismo e Constitucionalização do Direito (O Triunfo Tardio do Direito Constitucional no Brasil). Revista da EMERJ. 2006, p. 3-15. MARINONI, Luiz Guilherme; MITIDIERO, Daniel; SARLET, Ingo Wolgang. Curso de Direito Constitucional. São Paulo: Editora Revista dos Tribunais, 2012.
}

47 BRASIL. Constituição da República Federativa do Brasil de 1988. Disponível em: https://www.planalto.gov.br/ccivil_03/constituicao/constituicaocompilado.htm. Acesso em: 6 jul. 2017.

48 BARROSO. Neoconstitucionalismo e Constitucionalização do Direito (O Triunfo Tardio do Direito Constitucional no Brasil). Revista da EMERJ. 2006, p. 6-15.

49 Legislações como civil, ambiental, penal e processual (no caso deste trabalho o Direito Processual Civil), por exemplo, não escaparam dessa modificação.

50 NUNES, Dierle José Coelho. Processo Jurisdicional Democrático. 1a. ed. Curitiba: Editora Juruá, 2012, p. 156. 
MÖLLER, Guilherme Christen. A formação do direito processual civil brasileiro contemporâneo. Revista Eletrônica Direito e Política, Programa de Pós-Graduação Stricto Sensu em Ciência Jurídica da UNIVALI, Itajaí, v.13, n.2, $2^{\circ}$ quadrimestre de 2018. Disponível em: www.univali.br/direitoepolitica - ISSN 1980-7791

Constituição Federal (CF/88), que acima do individual, zelava pelo social, com a promoção de interesses difusos e coletivos. ${ }^{51}$

O referido período, além do fator acima exposto, é caracterizado por uma onda de constitucionalização das legislações infraconstitucionais, fenômeno associado a um efeito expansivo das próprias normas constitucionais, fazendo com que seu conteúdo material e axiológico se irradia por todo o sistema jurídico com força de norma. Com isso, os fins públicos, os valores e os comportamentos contemplados na Constituição Federal de 1988 foram responsáveis por condicionar a validade e o sentido de todas as normas da seara do direito infraconstitucional. ${ }^{52}$

A manifestação da constitucionalização no processual civil, se deu em duas visões, a primeira, na incorporação aos textos constitucionais de norma processual como direito fundamental ${ }^{53}$, e a segunda, no exame, pela doutrina, das normas processuais como concretizadoras das disposições da Constituição Federal. ${ }^{54}$

Essa mudança de paradigmas processuais levou a pensar se haveria a necessidade da elaboração de uma nova codificação processual para enquadrar a ciência processual civil à essa nova visão neoconstitucionalista.

Alfredo Buzaid, nas palavras de THEODORO JÚNIOR, alcançou um "perfectibilidade processual" com o Código de Processo Civil de 1973, todavia, a quantidade de emendas realizadas ao $\mathrm{CPC} / 73$ com o objetivo de aprimorar sua técnica acabou culminando uma desconfiança social sobre o seu texto, chegando-se a questionar

\footnotetext{
51 MÖLLER, Guilherme Christen. Anotações sobre a constitucionalização do Direito Processual Civil contemporâneo brasileiro. Curitiba: Prismas, 2017.

52 BARROSO. Neoconstitucionalismo e Constitucionalização do Direito (O Triunfo Tardio do Direito Constitucional no Brasil). Revista da EMERJ. 2006, p. 16.

53 Além de DIDIER JÚNIOR, Fredie (Curso de Direito processual civil. 17. Ed. Salvador: Juspodivm, 2015, v. 1), MONNERAT, Fábio Victor da Fonte (Introdução ao estudo do Direito Processual Civil. 2a. ed. São Paulo: Saraiva, 2017) acompanha essa visão.
}

54 DIDIER JÚNIOR, Fredie. Curso de Direito processual civil. 17. Ed. Salvador: Juspodivm, 2015, v. 1 . 
MÖLLER, Guilherme Christen. A formação do direito processual civil brasileiro contemporâneo. Revista Eletrônica Direito e Política, Programa de Pós-Graduação Stricto Sensu em Ciência Jurídica da UNIVALI, Itajaí, v.13, n.2, $2^{\circ}$ quadrimestre de 2018. Disponível em: www.univali.br/direitoepolitica - ISSN 1980-7791

a própria segurança jurídica na prestação efetiva da tutela jurisdicional civil para os jurisdicionados. ${ }^{55}$

Para MARINONI e MITIDIERO, uma nova codificação é oportuna quando apresenta uma renovação metodológica, do contrário, "se o que se pretende é a outorga de coesão ao direito processual civil e o acréscimo deste ou daquele instituto novo, colhe-se ensejo para simples consolidação", o que já vinha sendo feito anteriormente ao surgimento do novo direito constitucional brasileiro. ${ }^{56}$

Colhe-se da Exposição de Motivos do Anteprojeto que os trabalhos desenvolvidos para a elaboração do Código de Processo Civil de 2015, dentre outros objetivos, "estabelecer expressa e implicitamente verdadeira sintonia fina com a Constituição Federal" e "imprimir maior grau de organicidade ao sistema, dando-lhe, assim, maior coesão". ${ }^{57}$ Entretanto, não é a busca pela sintonia com a Constituição Federal e a organicidade ao sistema que implicaria na oportunidade de elaborar um novo código.

A elaboração de um novo código foi necessário pelo fato de que todas as mudanças sociais e jurídicas transcenderam a mera possibilidade de consolidação dos novos institutos, e, justamente por isso, os objetivos para a elaboração de uma nova codificação foram, além de "estabelecer expressamente e implicitamente verdadeira sintonia fina com a Constituição Federal" e "imprimir maior grau de organicidade ao sistema, dando-Ihe, assim, maior coesão", "criar condições para que o juiz possa proferir decisão de forma mais rente à realidade fática subjacente à causa", "simplificar, resolvendo problemas e reduzindo a complexidade de subsistemas", "dar todo rendimento possível a cada processo em si mesmo considerado". Por isso, viu-se a necessidade de uma nova legislação processual

\footnotetext{
55 THEODORO JÚNIOR, Humberto. Curso de Direito Processual Civil. 57. ed. Rio de Janeiro: Forense, 2016, p. 25.

56 MARINONI, Luiz Guilherme. MITIDIERO, Daniel. O projeto do CPC - Críticas e propostas. São Paulo: Editora Revista dos Tribunais, 2010, p. 56.

57 BRASIL. Projeto de Lei no 8.046/2010. Anteprojeto do Novo Código de Processo Civil. Disponível em: http://www.camara.gov.br/proposicoesWeb/fichadetramitacao?idProposicao=490267. Acesso em: 6 jul. 2017.
} 
MÖLLER, Guilherme Christen. A formação do direito processual civil brasileiro contemporâneo. Revista Eletrônica Direito e Política, Programa de Pós-Graduação Stricto Sensu em Ciência Jurídica da UNIVALI, Itajaí, v.13, n.2, $2^{\circ}$ quadrimestre de 2018. Disponível em: www.univali.br/direitoepolitica - ISSN 1980-7791

\section{civil $^{58}$ que se adequasse, pelo menos em teoria, as novas propostas dogmáticas} da Constituição Federal. 59

\footnotetext{
58 A afirmação é sustentada em MARINONI \& MITIDIERO, quando elencam diversas modificações e novidades do Anteprojeto ao vigente $C P C$, as quais tem condão de ensejar numa inovação legislativa processual civil: Com o objetivo de "esclarecer expressamente e implicitamente verdadeira sintonia fina com a Constituição Federal", arrolam-se as seguintes inovações: a) incidente de desconsideração da pessoa jurídica (art. 62 a 65); b) observância do contraditório como condição de decisão de matéria de ordem pública (art. 10 e 110 parágrafo único); c) imediata exigibilidade de multas coercitivas impostas para coagir ao cumprimento de decisões judiciais (art. 107, VI, e 503); d) publicação da data de julgamento de todo e qualquer recurso (art. 855); e) incidente de julgamento conjunto de demandas repetitivas (art. 895 a 906); f) criação de estímulos para a uniformização da jurisprudência, inclusive com incremento do sistema de julgamento de demandas repetitivas (arts. 895 a 906); f) criação de estímulos para uniformização da jurisprudência, inclusive com incremento do sistema de julgamento de recursos repetitivos (art. 847, 953 a 958); g) possibilidade de modulação de efeitos de decisão judicial que implique alteração de posicionamento jurisprudencial (art. 847, V); h) redução do prazo para propositura da ação rescisória para um ano (art. 893). Visando a "criar condições para que o juiz possa proferir decisão de forma mais rente à realidade fática subjacente à causa", listam-se: A) ênfase à mediação e à conciliação (arts. 107, IV, 134 a 144, 333, § 10; b) possibilidade de participação de amicus curiae no processo (art. 320); c) possibilidade de julgamento do mérito de recursos especiais e de recursos extraordinários relevantes para o fim de outorga de unidade ao Direito, ainda que não presentes alguns de seus requisitos de admissibilidade (art. 944, § $2^{\circ}$ ). Com o desiderato de "simplificar, resolvendo problemas e reduzindo a complexidade de subsistemas", arrolam-se: a) extinção da reconvenção, generalizando-se a possibilidade de pedido contraposto (art. 337); b) extinção do incidente de impugnação ao valor da causa, cuja inexatidão deve ser alegada como preliminar de contestação (art. 338, XIII); e do incidente de exibição de documentos (art. 375 a 383); c) extinção da exceção de incompetência relativa, que deve ser alegada como preliminar de contestação (art. 49 e 338, II); d) extinção da exceção de impedimento e de suspeição, que passa a ser alegada em simples petição (art. 116); e) extinção da ação declaratória incidental, uma vez que, respeitando o contraditório, a decisão da questão prejudicial fará coisa julgada (arts. 19 e 484), e da ação declaratória incidental de falsidade documental, que deve ser suscitada na contestação ou no prazo de cinco dias da juntada do documento aos autos (art. 410); f) reformulação do sistema de intervenção de terceiros $=$, com a extinção da oposição e da nomeação à autoria e com a fusão dos institutos da denunciação da lide e do chamamento ao processo em um único, designado simplesmente de chamamento (art. 327 a 332), sendo que, para efeitos de correção da legitimidade passiva e imediata extromissão do réu do processo, criou-se a possibilidade de emenda da petição inicial depois da contestação (art. 339); g) extinção dos procedimentos especiais de jurisdição contenciosa relativos à ação de depósito, à ação de anulação e substituição de títulos ao portador, à ação de nunciação de obra nova, à ação de usucapião de terras particulares, à ação de vendas a crédito com reserva de domínio e à ação monitória, e, de jurisdição voluntária, relativos à ação de especialização da hipoteca legal, sendo de se notar que a extinção dos procedimentos especiais relativos à ação de usucapião e à ação de anulação e substituição de títulos levou à criação de procedimento edital (art. 238); h) extinção das ações cautelares nominadas, com ressalvas das ações tratadas no Código vigente no Livro III, envolvendo a produção ou asseguração urgente da prova (produção antecipada de provas, justificação e exibição - arts. 271 a 276), as notificações e interpelações (arts. 660 a 663), a homologação do penhor legal (arts. 635 a 638) e a posse em nome do nascituro (arts. 694 a 696), adotando-se como regra geral a atipicidade das tutelas de urgência e de evidência (arts. 283 a 285); i) possibilidade de o advogado promover pelo correio a intimação das testemunhas (art. 434); j) extinção da distinção entre praça e leilão para efeitos de expropriação (arts. 750, II, e 802, I), bem como da necessidade de duas hastas públicas para arrematação do bem penhorado por valor inferior ao da avaliação, desde que não se trate de preço vil (art. 809); I) extinção dos embargos à arrematação, podendo a arrematação ser tornada sem efeito por simples petição nos autos da execução (art. 826, § $2^{\circ}$ ) ou anulada mediante ação anulatória (art. 894); m) unificação dos prazos processuais recursais para quinze dias, ressalvado o prazo dos embargos de declaração (art. 907, parágrafo único); n) extinção do juízo de admissibilidade da apelação pelo juízo de primeiro grau (art. 926); o) extinção do recursos de agravo retido, com a instituição da regra de inexistência de
} 
MÖLLER, Guilherme Christen. A formação do direito processual civil brasileiro contemporâneo. Revista Eletrônica Direito e Política, Programa de Pós-Graduação Stricto Sensu em Ciência Jurídica da UNIVALI, Itajaí, v.13, n.2, $2^{\circ}$ quadrimestre de 2018. Disponível em: www.univali.br/direitoepolitica - ISSN 1980-7791

As normas jurídicas derivam e devem estar em conformidade com a Constituição, e, justamente por isso que o Novo Código de Processo Civil, em seu artigo 10, sustenta que: "O processo civil será ordenado, disciplinado e interpretado conforme os valores e as normas fundamentais estabelecidos na Constituição da República Federativa do Brasil, observando-se as disposições deste Código" ${ }^{60}$.

preclusão das questões decididas antes da sentença por razões ou contrarrazões da apelação (art. 929, parágrafo único); p) cabimento casuístico do recurso de agravo de instrumento (art. 929), prevendo-se a possibilidade de sustentação oral nos agravos de instrumento que atacarem decisões de mérito (art. 857, $\S 1^{\circ}$ ); q) extinção do recuso de embargos infringentes; r) criação de regra que assegura o prequestionamento de questões constitucionais ou infraconstitucionais mediante a interposição em embargos de declaração, ainda que estes não tenham sido conhecidos, desde que o tribunal superior considere existentes omissão, contradição ou obscuridade(art. 940); s) nova sistemática de julgamento do recurso especial e recurso extraordinário quando o litígio apresentar múltiplos fundamentos em que se assentam ação e defesa (art. 949); t) vedação à extinção do processo por não conhecimento de recurso, caso o tribunal apontado como destinatário pelo recorrente entenda que a competência para exame do recurso é de outro tribunal, com conseguinte dever de remessa dos autos ao tribunal competente (arts. 947 e 948). Objetivando "dar todo rendimento possível a cada processo em si mesmo considerado", relacionam-se: a) extensão dos limites objetivos da coisa julgada às questões prejudicais (arts. 19 e 484); b) consideração do reconhecimento da impossibilidade jurídica do pedido como hipótese de sentença de mérito; c) criação do instituto da estabilização da tutela de urgência (arts. 287, § 10, 288, § 20, e 293); d) possibilidade de adição e de alteração do pedido e da causa de pedir até a sentença, desde que observados a boa-fé e o contraditório (art. 314); e) adaptação do processo às peculiaridades da causa (art. 107, V, e 151, § 10). Por fim, visando a "imprimir maior grau de organicidade ao sistema, dando-Ihe, assim, mais coesão", listam-se: a) criação da parte geral (Livro I); b) unificação das hipóteses em que é possível superar a preclusão consumativa ocasionada pela prolação da decisão de mérito (art. 476); c) organização das hipóteses que levam à extinção liminar do processo sem resolução de mérito (indeferimento da petição inicial - art. 315) ou com resolução de mérito (rejeição liminar da demanda - art. 317); d) unificação do critério que previne a competência, funcionando para tanto o despacho que ordena a citação (art. 44); e) alocação da homologação do penhor legal (arts. 635 a 638) nos procedimentos especiais de jurisdição contenciosa e das notificações e interpelações (arts. 660 a 663) e da posse em nome do nascituro (arts. 694 a 696) nos procedimentos especiais de jurisdição voluntária; f) criação de livro novo concernente aos processos nos tribunais e aos meios de impugnação das decisões judiciais (Livro IV), g) clareamento das hipóteses de cabimento de ação rescisória (art. 884) e de a ]ao anulatória (art. 894); h) disciplina das hipóteses de litisconsórcio necessário e unitário com maior rigor científico (arts. 102 a 104); i) correção da utilização dos termos substituição e sucessão processual (arts. 96 a 98); j) utilização do gênero convenção de arbitragem a fim de designar as suas duas espécies, clausula arbitral e compromisso arbitral, quando pertinente (arts. 337, X, e 497, VII). MARINONI, Luiz Guilherme. MITIDIERO, Daniel. O projeto do CPC - Críticas e propostas. São Paulo: Editora Revista dos Tribunais, 2010, p. 57-60.

59 MARINONI, Luiz Guilherme. MITIDIERO, Daniel. O projeto do CPC - Críticas e propostas. São Paulo: Editora Revista dos Tribunais, 2010, p. 56-57. BRASIL. Projeto de Lei no 8.046/2010. Anteprojeto do Novo Código de Processo Civil. Disponível em: http://www.camara.gov.br/proposicoesWeb/fichadetramitacao?idProposicao=490267. Acesso em: 6 jul. 2017.

60 BRASIL. Lei no 13.105, de 16 de março de 2015. Código de Processo Civil. Disponível em: http://www.planalto.gov.br/ccivil_03/_ato2015-2018/2015/lei/l13105.htm. Acesso em: 6 jul. 2017. Art. $1^{\circ}$. 
MÖLLER, Guilherme Christen. A formação do direito processual civil brasileiro contemporâneo. Revista Eletrônica Direito e Política, Programa de Pós-Graduação Stricto Sensu em Ciência Jurídica da UNIVALI, Itajaí, v.13, n.2, $2^{\circ}$ quadrimestre de 2018. Disponível em: www.univali.br/direitoepolitica - ISSN 1980-7791

Não é a elaboração de uma nova codificação processual civil que fará com que a nova hermenêutica seja aplicada, afinal, para que essa seja aplicada é necessário a mudança de pensamento por parte dos juristas (em sentido lato sensu) e o confronto da norma processual com o texto constitucional61.62

O neoconstitucionalismo brasileiro é responsável por iniciar uma nova fase para cada ciência infraconstitucional, inclusive no Direito Processual Civil ${ }^{63}$, tendo como principais características um processo cooperativo ${ }^{64}$, justo e democrático, sob a ótica de pensamentos contemporâneos ${ }^{65}$. Não é o Código de Processo Civil de 2015 o responsável por essa conquista, pelo contrário, ele é apenas a ferramenta

${ }^{61}$ Sobre a questão, TALAMINI, Eduardo \& WAMBIER, Luiz Rodrigues, apontam que: A Constituição Federal é o ponto de partida para a compreensão mais adequada do que é o processo civil. É em suas normas que podemos extrair a essência, a finalidade e a forma do processo em um Estado Democrático de Direito. Todo o ordenamento jurídico brasileiro, na verdade, é regido pela Constituição Federal. Assim, há muito tempo que a simples remissão à lei deixou de ser suficiente para a compreensão não apenas do direito processual civil, mas também dos demais ramos e disciplinas do Direito. Em se tratando especificamente do Processo Civil, isso significa que as normas do Código de Processo Civil ou da legislação processual civil extravagante, como um todo, somente podem ser integradas e satisfatoriamente interpretadas em cotejo com aquelas dispostas na Constituição Federal, isto é, não se bastam sozinhas. É a própria Constituição que orienta todo o "dever-ser" do processo e de todos os seus temas e institutos. Assim, o direito processual civil e cada um de seus institutos devem ser compatíveis com os preceitos constitucionais e destinados à realização de seus valores, de forma a maximizá-los por meio do processo, através tanto do atingimento da pacificação social quanto dos próprios objetivos do Estado elencados na Constituição Federal. (TALAMINI, Eduardo; WAMBIER, Luiz Rodrigues. Curso avançado de Processo Civil. v.1. 15a. ed. São Paulo: Editora Revista dos Tribunais, 2015, p. 67.

62 DIDIER JÚNIOR. Curso de Direito processual civil. 17ed.Salvador: Juspodivm, 2015, v1, p47.

63 A nomenclatura da quarta fase da ciência processual civil brasileira não é unânime, a quem prefira denomina-la de de neoconstitucionalismo, outros de neoprocessualismo, e ainda quem prefira chama-la de formalismo valorativo. DIDIER JúNIOR. Curso de Direito processual civil. 17. Ed. Salvador: Juspodivm, 2015, v. 1, p. 42-45.

64 DIDIER JUNIOR, Fredie. Os três modelos de direito processual: inquisitivo, dispositivo e cooperativo. Disponível em: https://edisciplinas.usp.br/pluginfile.php/364050/mod_resource/content/0/FREDIE\%20DIDIER\%20 -\%200s\%20tr\%C3\%AAs\%20modelos\%20de\%20processo\%20-

\%20dispositivo,\%20inquisitivo\%20e\%20cooperativo.pdf $>$. Acesso em: 6 jul. 2017. ARENHART, Sérgio Cruz; MARINONI, Luiz Guilherme; MITIDIERO, Daniel. Novo curso de processo civil: teoria do processo civil, volume 1. 2. ed. rev., atual. e ampl. São Paulo: Editora Revista dos Tribunais, 2016.

65 Fredie Didier Júnior (Curso de Direito processual civil. 17. Ed. Salvador: Juspodivm, 2015, v. 1, p. 39-42) elenca quatro características do pensamento processual contemporâneo: 1) Reconhecimento da força normativa da Constituição; 2) Desenvolvimento da teoria dos princípios; 3) Transformação da hermenêutica jurídica; e 4) Expansão e consagração dos direitos fundamentais. 
MÖLLER, Guilherme Christen. A formação do direito processual civil brasileiro contemporâneo. Revista Eletrônica Direito e Política, Programa de Pós-Graduação Stricto Sensu em Ciência Jurídica da UNIVALI, Itajaí, v.13, n.2, $2^{\circ}$ quadrimestre de 2018. Disponível em: www.univali.br/direitoepolitica - ISSN 1980-7791

legislativa que irá potencializar essa nova tendência processual, mesmo que há quem discorde dessa afirmação ${ }^{66} \cdot{ }^{67}$

\title{
2.4 O Código DE PROCESSO CIVIL DE 2015 COMO fERRAMENTA LEGISLATIVA POTENCIALIZADORA DA NOVA TENDÊNCIA PROCESSUAL E
} A CONSTANTE BUSCA PELA EFETIVIDADE DA TUTELA JURISDICIONAL

\author{
Antes da reforma legislativa de uma codificação processual é necessário o \\ rompimento de ideologias arcaicas sobre a matéria, e plantar uma ideia de \\ supervalorizar a prestação de uma tutela jurisdicional justa, ainda mais com a \\ crescente ideia de constitucionalização. ${ }^{68}$
}

O Novo Código de Processo Civil foi desenhado e construído para atender a missão de um processo cooperativo e justo, o menos formal possível, buscando assumir o caráter de instrumento de efetivação do direito material ${ }^{69}$, especialmente quando se tratar de direitos fundamentais. ${ }^{70}$

\footnotetext{
66 Fernando Gonzaga Jayme (Necessitamos de um Novo Código de Processo Civil? In: Processo Civil - Novas tendências. FARIA, Juliana Cordeiro de; JAIME, Fernando Gonzaga; LAUAR, Maria Terra (coord.). Belo Horizonte: Del Rey, 2011, p. 229-230). Destaca que o fato da elaboração do Projeto de Código de Processo Civil não ter sido precedida de estudos prévios de impacto da legislação em vigor, com o fim de identificar possíveis problemas a serem solucionados apresenta uma certa viabilidade prática questionável, de modo que poderia agravar problemas como morosidade na prestação da prestação jurisdicional. A conclusão do autor pode ter sido elaborada nesses moldes pelo fato do anteprojeto do vigente código ter surgido no ano de 2010 e a referida obra ter sido publicada no ano de 2011. Com a devida vênia ao autor, pensa-se que o anteprojeto do Código de Processo Civil de 2015 teve tempo mais do que suficiente para estudo e discussão desde sua apresentação em 2015, até sua aprovação em 2015. O Novo Código de Processo Civil tem mostrado, até este ano de 2017, bom resultado prático em diversas questões, e está buscando a modificação da mentalidade não só dos juristas, bem como de toda a população brasileira acerca da forma de como ver o litígio. Pensa-se que as ideias sociais zeladas pela Constituição Federal de 1988, por meio do cooperativismo do Código de Processo Civil de 2015, serão alcançadas em algumas décadas.
}

67 MÖLLER, Guilherme Christen. Anotações sobre a constitucionalização do Direito Processual Civil contemporâneo brasileiro. Curitiba: Prismas, 2017.

68 THEODORO JÚnIOR, Humberto. Curso de Direito Processual Civil. 57. ed. Rio de Janeiro: Forense, 2016, p. 29.

69 NOGUEIRA, Antonio de Pádua Ferra. Questões controvertidas de Processo Civil e de direito material. São Paulo: Editora Revista dos Tribunais, 2001.

70 TheOdORO JÚnIOR, Humberto. Curso de Direito Processual Civil. 57. ed. Rio de Janeiro: Forense, 2016, p. 30. 
MÖLLER, Guilherme Christen. A formação do direito processual civil brasileiro contemporâneo. Revista Eletrônica Direito e Política, Programa de Pós-Graduação Stricto Sensu em Ciência Jurídica da UNIVALI, Itajaí, v.13, n.2, $2^{\circ}$ quadrimestre de 2018. Disponível em: www.univali.br/direitoepolitica - ISSN 1980-7791

Antes de considerar aspectos do novo Código que se relacionam com a tutela dos direito fundamentais processuais, importa esclarecer que os valores constitucionais que fundamentam o processo civil contemporâneo não se contentam somente com a ideia de procedimento orientado pelas garantias de participação adequada, mas reclamam que os procedimento também seja capaz de atender às situações de direito material e às necessidades sociais carentes de tutela jurisdicional e, além disso, exigem que as decisões judiciais expressem o conteúdo dos direitos fundamentais. Em outros termos, direito à tutela judicial efetiva e processo são elementos que se conjugam quando se tem um processo civil preocupado com a tutela dos direitos. O processo deve observar os direitos fundamentais processuais que garantem a participação dos jurisdicionados e o adequado oferecimento das suas razões, mas deve estar estruturado de modo a viabilizar o efetivo alcance das tutelas dos direitos, sem que a decisão judicial se afaste do seu compromisso com as normas constitucionais. ${ }^{71}$

O Código de Processo Civil é pensado e desenvolvido para ser uma ferramenta legislativa potencializadora da nova tendência processual, com o fim de buscar a melhor efetividade da tutela jurisdicional para cada processo, respeitando garantias constitucionais do processo ${ }^{72}$ e promovendo o fim da "cultura do litigio", que havia se consolidado no Brasil, viabilizando outras formas de solucionar os conflitos, buscando um processo cooperativo "entre" os jurisdicionados ${ }^{73}$

O processo justo, nova tendência do Direito Processual Civil e evolução da ideia publicista do CPC de 1939, observa um modelo social de processo, ensejando na instrumentalidade, efetividade e promoção da tutela dos direitos subjetivos ${ }^{74}$, possibilitando alcançar a realidade fática de cada processo, afim de que seja

${ }^{71}$ ARENHART, Sério Cruz; MARINONI, Luiz Guilherme. MITIDIERO, Daniel. O novo Processo Civil. São Paulo: Editora Revista dos Tribunais, 2015, p. 83.

72 CRUZ E TUCCI, José Rogério. Garantias Constitucionais do Processo Civil. São Paulo: Editora Revista dos Tribunais, 1999.

73 TheOdoro Júnior, Humberto. Curso de Direito Processual Civil. 57. ed. Rio de Janeiro: Forense, 2016, p. 25-26.

74 TheOdORO JÚnIOR, Humberto. Curso de Direito Processual Civil. 57. ed. Rio de Janeiro: Forense, 2016, p. 26. 
MÖLLER, Guilherme Christen. A formação do direito processual civil brasileiro contemporâneo. Revista Eletrônica Direito e Política, Programa de Pós-Graduação Stricto Sensu em Ciência Jurídica da UNIVALI, Itajaí, v.13, n.2, $2^{\circ}$ quadrimestre de 2018. Disponível em: www.univali.br/direitoepolitica - ISSN 1980-7791

"vitorioso" em cada processo àquele que tiver a verdade em seu favor, protegendo-se a situação jurídica pelo pronunciamento judicial. ${ }^{75}$

A premissa para um processo civil contemporâneo e missão do Novo Código de Processo Civil consiste na busca da possibilidade de aproximação com o direito material ${ }^{76}$, de modo que a técnica processual não deva mais ser vista como tendo um fim em si ou um autovalor, mesmo que essa possua sua autonomia, afinal, a função do processo é, enquanto instrumento de prestação de tutela jurisdicional, a instrumentalização das regras substanciais existentes no ordenamento jurídico "quando estas se deparam com a crise de sua inobservância in concreto"n7, deixando a preocupação com conceitos e formas à limiar e zelando por encontrar "mecanismos destinados a conferir à tutela jurisdicional o grau de efetividade que dela se espera"78, não significando rejeitar o direito posto, pelo contrário, afinal, quanto mais adequado a tutela jurisdicional dos direitos subjetivos substanciais for prestada, mais efetivo será o desempenho pela técnica processual. ${ }^{79}$

Se é para pensar em nova codificação para o processo civil, é imprescindível que o Código apareça marcado pela nossa cultura - que é a cultura do Estado Constitucional - e possa servir à prática sem descurar das imposições que são próprias

\footnotetext{
75 SOUZA, Miguel Teixeira de. Um novo processo civil português: à la recherche du temps perdu? Novos rumos da Justiça Cível. Coimbra: Centro de Estudos Judiciários, 2009, p. 17.

76 Sobre essa aproximação, ensina, Francesco Carnelutti (Profilo dei rapporti tra diritto e processo. Rivista di Diritto Processuale, ano 35, n. 4, p. 64.): "tra diritto e processo existe um rapporto logico circolare: il processo serve al diritto, ma affinchè serva al diritto deve essere servitto dal diritto.". Traduzindo-se a lição do professor CARNELUTTI, significa que entre o Direito material e o processo existe uma relação circular, sendo que o processo serve ao Direito material, mas para que Ihe sirva é necessário que seja servido por ele. Entra-se, aqui, em uma discussão acerca da teoria circular dos planos, a relação entre Direito material e Direito processual, e, em suma, essa teoria, seguindo-se os ensinamentos do professor CARNELUTTI, inobstante ao fato da autonomia de cada ramo da ciência processual, inclusive, estando em planos distintos, um depende do outro, porquanto o Direito material projeta, faz planos, idealiza uma sociedade justa e igualitária, enquanto, o processual, põe em prática. Os dois ramos se completam, e não concorrem entre si. Nesse sentido, CARACIOLA, Andrea Boari. Direito material e Direito processual. In: Teoria Geral do Processo Contemporâneo. CARACIOLA, Andrea Boari; DE ASSIS, Carlos Augusto; DE SOUZA, André Pagani; DELLORE, Luiz; FERNANDES, Eduardo Simardi. São Paulo: Atlas, 2016, p. 24.
}

77 TheOdoro Júnior, Humberto. Curso de Direito Processual Civil. 57. ed. Rio de Janeiro: Forense, 2016, p. 23.

78 BEDAQUE, José Roberto dos S. Efetividade do processo e técnica processual: tentativa de compatibilização. Tese para concurso de Professor Titular, USP, São Paulo: 2005, p. 13.

79 THEODORO JÚnIOR, Humberto. Curso de Direito Processual Civil. 57. ed. Rio de Janeiro: Forense, 2016, p. 23. 
MÖLLER, Guilherme Christen. A formação do direito processual civil brasileiro contemporâneo. Revista Eletrônica Direito e Política, Programa de Pós-Graduação Stricto Sensu em Ciência Jurídica da UNIVALI, Itajaí, v.13, n.2, $2^{\circ}$ quadrimestre de 2018. Disponível em: www.univali.br/direitoepolitica - ISSN 1980-7791

da ciência jurídica, como necessidade de ordem e unidade, sem as quais não há como falar em sistema nem tampouco cogitar da coerência que lhe é essencial. Isto quer dizer que o Código deve ser pensado a partir de eixos temáticos fundados em sólidas bases teóricas. Um Código de Processo Civil, como parece óbvio, deve ser orientado a partir de uma linha teórica. Não Ihe basta o instituto pragmático. É a partir da sua inspiração teórica que se pode surpreender a sua unidade. Fora daí, corre-se o grave risco de codificar-se sem sistema. Rigorosamente, aliás, não se poderia sequer falar em um Código sem que nele se exprimisse um sistema - sistema que no Estado Constitucional, diga-se de passagem, deve ser qualificado como um sistema de autorreferências relativa ou relativamente aberto, dada a nova teoria das normas e a técnica legislativa que Ihe são próprias. Isso de modo nenhum quer dizer, todavia, que um Código de Processo Civil não deve servir à prática ou, muito menos, que não deve se preocupar com problemas concretos. É claro que não. Um Código de processo Civil tem antes de qualquer coisa um compromisso inafastável com o foro. Deve servi-lo. Este compromisso, contudo, deve ser entendido e ampliado dentro de um quadro teórico coerente. A recíproca implicação entre teoria e prática deve ser constante a fim de que a legislação processual civil possa constituir meio efetivamente idôneo para resolver problemas concretos, cumprindo com o seu desiderato de outorga adequada proteção ao direito fundamental ao devido processo. Para que o direito processual civil possa realmente ter a sua âncora na Constituição e ser compreendido como verdadeiro instrumento de efetiva proteção dos direitos, é fundamental que todo o processo civil seja orientado pelo direito material. Muito especialmente, que todo o processo seja pensado a partir da teoria da tutela dos direitos. Vale dizer: em atenção às situações substanciais carentes de tutela no plano do direito material. Se tem um direito significa antes de tudo ter uma posição juridicamente tutelável, então não há compromisso mais importante dentro do Estado Constitucional, em termos de processo civil, do que primeiro identificarem-se quais são as tutelas possíveis aos direitos. Só depois disso é que é possível cogitar da segunda etapa: aferir quais as técnicas processuais que devem ser prestadas mediante processo justo para realização do direito material. Um Código de Processo Civil que não se preocupa em bem relacionar direito e processo a partir de adequada teorização do sistema de tutela dos direitos, mediante o emprego de expressões suficientemente abertas que permitam a adequação da ação à tutela do direito pretendido pelo demandante, não pode ser encarado como um Código realmente engajado na efetivação do direito material nas suas mais variadas manifestações. Mas isto, como é pouco mais do 
MÖLLER, Guilherme Christen. A formação do direito processual civil brasileiro contemporâneo. Revista Eletrônica Direito e Política, Programa de Pós-Graduação Stricto Sensu em Ciência Jurídica da UNIVALI, Itajaí, v.13, n.2, $2^{\circ}$ quadrimestre de 2018. Disponível em: www.univali.br/direitoepolitica - ISSN 1980-7791

que evidente, não é tudo. Se é necessário primeiro pensar o direito material, bem identificando as tutelas por eles prometidas, para organização de um Código de Processo Civil no Estado Constitucional, não menos importante é pensar de que forma o processo deve se estruturar a fim de que possa se apresentar realmente como um processo justo, como um processo adequado aos fins a ele colimados pelo próprio Estado Constitucional. Isto obviamente depende de particular visão a respeito das relações que se estabelecem entre o juiz e as partes e das linhas mestras que devem presidir a densificação de nosso modelo constitucional de processo. Sem que se tenha, em outras palavras, bem presentes a necessidade de colaboração do Estado para com as partes já que o Estado não mais se afigura como o inimigo público número um e hoje tem também o dever de prestar para viabilizar a realização dos direitos fundamentais processuais civis que compõem o direito ao processo justo na legislação infraconstitucional, pouco se pode escapar em termos de redação de um Código de Processo Civil. Sem atenção à Constituição, ao direito material e à realidade social, um Código de Processo Civil pouco pode em termos de adequada, efetiva e tempestiva tutela das situações substancias. ${ }^{80}$

Os apontamentos feitos por MARINONI e MITIDIERO em 2010, quando do início da discussão do anteprojeto do que viria a ser o Código de Processo Civil de 2015, foram concretizados com a aprovação do vigente código, todavia, de nada adianta elaborar um código nessas vertentes se a sua aplicação for feita pensando numa legislação pretérita.

Uma das principais linhas do CPC de 2015 é a de zelar pelo direito fundamental ao acesso à justiça em elevado grau, afinal, não basta assegurar um processo justo e cooperativo, com a devida tutela dos direitos na seara material, se não houver a possibilidade de exercer o direito a uma tutela jurisdicional, inclusive quando da opção doutras formas que não a jurisdição estatal. ${ }^{81}$

Certo é, de qualquer forma, que quando a Constituição Federal consagra o princípio da inafastabilidade da tutela jurisdicional (art. 50, inciso XXXV, da Constituição Federal), tal previsão constitucional deve ser interpretada como

\footnotetext{
80 MARINONI, Luiz Guilherme. MITIDIERO, Daniel. O projeto do CPC - Críticas e propostas. São Paulo: Editora Revista dos Tribunais, 2010, p. 60-61.

81 ARANHART, Sério Cruz; MARINONI, Luiz Guilherme; MITIDIERO, Daniel. Novo Curso de Processo Civil. v.1. São Paulo: Editora Revista dos Tribunais, 2015.
} 
MÖLLER, Guilherme Christen. A formação do direito processual civil brasileiro contemporâneo. Revista Eletrônica Direito e Política, Programa de Pós-Graduação Stricto Sensu em Ciência Jurídica da UNIVALI, Itajaí, v.13, n.2, $2^{\circ}$ quadrimestre de 2018. Disponível em: www.univali.br/direitoepolitica - ISSN 1980-7791

garantia das partes à ordem jurídica justa, aos meios adequados de solução de controvérsias, não obrigatoriamente pela via da heterocomposição, e muito menos necessariamente pela via jurisdicional estatal. ${ }^{82}$

O processo não mais pertence exclusivamente ao juiz, como era numa visão processual arcaica, afinal, é cooperativo a fim de que todos os sujeitos do processo atuem de forma ativa para zelar por um processo justo. ${ }^{83}$

\section{CONSIDERAÇÕES FINAIS}

Com esta breve digressão, conclui-se que a trajetória do Direito Processual Civil brasileiro foi influenciada por diversos momentos da sua história, em especial pela forte onda de constitucionalização dos direitos infraconstitucionais e da tendência social oriunda de movimentos neoconstitucionalistas iniciadas na metade do século passado.

Foi a disputa dessa visão social e democrática da Constituição Federal de 1988 contra o forte caráter individualista do Direito Processual Civil que ensejou na necessidade da reformulação da cultura desse ramo e, por conseguinte, na elaboração de um novo Código de Processo Civil.

A premissa para um processo civil contemporâneo e missão de um novo código consiste em buscar a possibilidade de aproximar o direito material e o direito processual, deixando a preocupação com conceitos e formas à limiar e zelando por encontrar mecanismos que confiram à tutela jurisdicional o grau de efetividade que dela se espera.

O Novo Código de Processo Civil foi desenhado e construído para atender a missão de um processo cooperativo e justo, zelando pelo acesso à justiça em elevado grau

82 FERNANDES, Luis Eduardo Simardi. Formas de solução dos litígios. In: Teoria Geral do Processo Contemporâneo. CARACIOLA, Andrea Boari; DE ASSIS, Carlos Augusto; DE SOUZA, André Pagani; DELLORE, Luiz; FERNANDES, Eduardo Simardi. São Paulo: Atlas, 2016, p. 11.

83 THEODORO JÚNIOR, Humberto. Curso de Direito Processual Civil. 57. ed. Rio de Janeiro: Forense, 2016, p. 26. 
MÖLLER, Guilherme Christen. A formação do direito processual civil brasileiro contemporâneo. Revista Eletrônica Direito e Política, Programa de Pós-Graduação Stricto Sensu em Ciência Jurídica da UNIVALI, Itajaí, v.13, n.2, $2^{\circ}$ quadrimestre de 2018. Disponível em: www.univali.br/direitoepolitica - ISSN 1980-7791

e devendo assumir a forma de ferramenta legislativa potencializadora dessa nova tendência processual.

O processo não mais pertence exclusivamente ao juiz, afinal, é cooperativo a fim de que todos os sujeitos do processo atuem de forma ativa para zelar por um processo justo.

Todavia, antes da reforma legislativa de uma codificação processual é necessário o rompimento de ideologias arcaicas sobre a matéria e plantar uma ideia de supervalorizar a prestação de uma tutela jurisdicional justa. Não é a elaboração de um novo código que fará com que as novas linhas metodológicas do processo civil sejam aplicadas, para isso é necessário a mudança de pensamento por parte dos juristas.

\section{REFERÊNCIAS BIBLIOGRÁFICAS}

AGUIAR, Renan; MACIEL, José Fabio Rodrigues. História do Direito. 7a. ed. São Paulo: Saraiva, 2016.

ARENHART, Sério Cruz; MARINONI, Luiz Guilherme. MITIDIERO, Daniel. O novo Processo Civil. São Paulo: Editora Revista dos Tribunais, 2015.

Novo curso de processo civil: teoria do processo civil, v. 1. $2^{\text {a }}$. ed. rev., atual. e ampl. São Paulo: Editora Revista dos Tribunais, 2016.

BARROSO, Luís Roberto. Neoconstitucionalismo e Constitucionalização do Direito (O Triunfo Tardio do Direito Constitucional no Brasil). Revista da EMERJ, Rio de Janeiro, v. 9, n. 33, 2006.

BEDAQUE, José Roberto dos Santos. Efetividade do processo e técnica processual: tentativa de compatibilização. Tese para concurso de Professor Titular, USP, São Paulo: 2005.

BERMUDES, Sergio. Comentários ao Código de Processo Civil. São Paulo: Editora Revista dos Tribunais, 1975. v. II. n. 7.

BRASIL. Constituição da República dos Estados Unidos do Brasil. Disponível em: http://www.planalto.gov.br/ccivil_03/Constituicao/Constituicao34.htm. Acesso em: 6 jul. 2017.

. Constituição da República Federativa do Brasil de 1988. Disponível em: https://www.planalto.gov.br/ccivil_03/constituicao/constituicaocompilado.htm. Acesso em: 6 jul. 2017. 
MÖLLER, Guilherme Christen. A formação do direito processual civil brasileiro contemporâneo. Revista Eletrônica Direito e Política, Programa de Pós-Graduação Stricto Sensu em Ciência Jurídica da UNIVALI, Itajaí, v.13, n.2, $2^{\circ}$ quadrimestre de 2018. Disponível em: www.univali.br/direitoepolitica - ISSN 1980-7791

Decreto no. 737, de 25 de novembro de 1850. Disponível em: <http://www.planalto.gov.br/ccivil_03/decreto/Historicos/DIM/DIM737.htm>. Acesso em: 6 jul. 2017.

Lei no 5.869, de 11 de janeiro de 1973. Código de Processo Civil. Disponível em: http://www.planalto.gov.br/ccivil_03/leis/L5869.htm. Acesso em: 6 jul. 2017.

. Lei no 8.952, de 13 de dezembro de 1994. Disponível em: <http://www.planalto.gov.br/ccivil_03/leis/L8952.htm>. Acesso em: 6 jul. 2017. 2018/2015/lei/l13105.htm. Acesso em: 6 jul. 2017.

BRASIL. Projeto de Lei no 8.046/2010. Anteprojeto do Novo Código de Processo Civil.

http://www.camara.gov.br/proposicoesWeb/fichadetramitacao?idProposicao=490 267. Acesso em: 6 jul. 2017.

CARACIOLA, Andrea Boari; DE ASSIS, Carlos Augusto; DE SOUZA, André Pagani; DELLORE, Luiz; FERNANDES, Eduardo Simardi. Teoria Geral do Processo Contemporâneo. São Paulo: Atlas, 2016.

CARNELUTTI, Francesco. Profilo dei rapporti tra diritto e processo. Rivista di Diritto Processuale, ano 35, n. 4.

CINTRA, Araújo; DINAMARCO, Cândido Rangel; GRINOVER, Ada Pellegrini; Teoria geral do processo. São Paulo: Malheiros, 2013.

COSTA, Lopes. Manual elementar de Direito processual civil. Rio de Janeiro: Forense, 1956, n. 56.

CRUZ E TUCCI, José Rogério. Garantias Constitucionais do Processo Civil. São Paulo: Editora Revista dos Tribunais, 1999.

DIDIER JÚNIOR, Fredie. Curso de Direito processual civil. 17a. Ed. Salvador: Juspodivm, 2015, v. 1.

DIDIER JUNIOR, Fredie. Os três modelos de direito processual: inquisitivo, dispositivo e cooperativo. Disponível em: < https://edisciplinas.usp.br/pluginfile.php/364050/mod_resource/content/0/FREDI E\%20DIDIER\%20-

\%200s\%20tr\%C3\%AAs\%20modelos\%20de\%20processo\%20-

$\% 20$ dispositivo,\%20inquisitivo\%20e\%20cooperativo.pdf $>$. Acesso em: 6 jul. 2017.

FARIA, Juliana Cordeiro de; JAIME, Fernando Gonzaga; LAUAR, Maria Terra (coord.). Processo Civil - Novas tendências. Belo Horizonte: Del Rey, 2011. 
MÖLLER, Guilherme Christen. A formação do direito processual civil brasileiro contemporâneo. Revista Eletrônica Direito e Política, Programa de Pós-Graduação Stricto Sensu em Ciência Jurídica da UNIVALI, Itajaí, v.13, n.2, $2^{\circ}$ quadrimestre de 2018. Disponível em: www.univali.br/direitoepolitica - ISSN 1980-7791

GRECO, Leonardo. Publicismo e Privatismo no Processo Civil. In: Revista de Processo. vol. 164/2008. Out/2008. p. 29 - 56.

MARINONI, Luiz Guilherme. MITIDIERO, Daniel. O projeto do CPC - Críticas e propostas. São Paulo: Editora Revista dos Tribunais, 2010.

MARINONI, Luiz Guilherme; MITIDIERO, Daniel; SARLET, Ingo Wolgang. Curso de Direito Constitucional. São Paulo: Editora Revista dos Tribunais, 2012.

MÖLLER, Guilherme Christen. A constitucionalização do direito processual civil contemporâneo brasileiro. 2016. 147 f. Trabalho de Conclusão de Curso (Graduação em Direito) - Centro de Ciências Jurídicas, Universidade Regional de Blumenau, Blumenau, 2016. Disponível em: <http://www.bc.furb.br/docs/MO/2016/362006_1_1.pdf>. Acesso em: 6 jul. 2017.

Anotações sobre a constitucionalização do Direito Processual Civil contemporâneo brasileiro. Curitiba: Prismas, 2017.

MONNERAT, Fábio Victor da Fonte. Introdução ao estudo do Direito Processual Civil. 2a. ed. São Paulo: Saraiva, 2017.

NOGUEIRA, Antonio de Pádua Ferra. Questões controvertidas de Processo Civil e de direito material. São Paulo: Editora Revista dos Tribunais, 2001.

NUNES, Dierle José Coelho. Processo Jurisdicional Democrático. $1^{\text {a }}$. ed. Curitiba: Editora Juruá, 2012.

PINHO, Humberto Dalla Berdina de. Direito Processual Civil contemporâneo. 5a. ed. São Paulo: Saraiva, 2013.

ROMANO, Santi. Princípios de Direito constitucional geral. Trad. Maria Helena Diniz. São Paulo: Editora Revista dos Tribunais, 1977.

SANTOS, Moacyr Amaral. Primeiras linhas de Direito Processual Civil. 28a. ed. São Paulo: Saraiva, 2011.

SOUZA, Miguel Teixeira de. Um novo processo civil português: à la recherche du temps perdu? Novos rumos da Justiça Cível. Coimbra: Centro de Estudos Judiciários, 2009.

TALAMINI, Eduardo; WAMBIER, Luiz Rodrigues. Curso avançado de Processo Civil. 15a. ed. São Paulo: Editora Revista dos Tribunais, 2015, v.1.

THEODORO JúnIOR, Humberto. Curso de Direito Processual Civil. 57. ed. Rio de Janeiro: Forense, 2016.

Recebido em: 09/12/2016

Aprovado em: 26/07/2017 